\title{
Political budget cycles and media freedom
}

\author{
Francisco José Veiga* \\ Universidade do Minho, NIPE \\ fjveiga@eeg.uminho.pt \\ Linda Gonçalves Veiga \\ Universidade do Minho, NIPE \\ linda@eeg.uminho.pt \\ Atsuyoshi Morozumi \\ University of Nottingham, CFCM, NICEP \\ Atsuyoshi.Morozumi@nottingham.ac.uk
}

\begin{abstract}
:
This paper examines the effects of elections on the conduct of central governments' fiscal policies. To do so, it uses a unique panel database that includes disaggregated spending and revenue series at the central government level for multiple countries over the 1975-2010 period. Examining political environments under which incumbent governments generate political budget cycles (PBCs), and comparing the relative importance of factors influencing cycles, we identify media freedom as the factor that plays the most critical role. This result provides a micro-foundation for rational opportunistic models for PBCs that rely on asymmetry of information about politicians' competence, and also offers a way to relate different conditioning factors of PBCs, including fiscal transparency and the maturity of democracies. Further, we show that the election-year rise in budget deficits under low media freedom is primarily driven by an increase in the current, not capital, component of public expenditure.
\end{abstract}

Keywords: Political budget cycles; Central government; Voter information; Media Freedom; Fiscal policy composition

* Corresponding author: Universidade do Minho, Escola de Economia e Gestão, 4710-057 Braga, Portugal. E-mail: fjveiga@eeg.uminho.pt. Tel.: +351 253604534. Fax: +351 253601380. 


\section{Introduction}

Which political considerations best explain the occurrence of political budget cycles? And, which components of public spending and revenue are manipulated prior to elections in response to considerations?

To address these questions, we assemble a new comprehensive dataset on disaggregated expenditure and revenue series, which covers around 70 developed and developing countries over the period $1975-2010$ at the central government level. We first examine circumstances under which fiscal manipulations may occur. Specifically, we condition our analysis on various political considerations suggested by the political budget cycle (PBC) literature: 1) those affecting the readiness and incentives of incumbent politicians to behave opportunistically; and, 2) those affecting the capacity of the opportunistic measures to yield additional votes. Then, after checking how each of these factors shapes PBCs in the context of our dataset, we systematically compare their relative importance, to identify the one that plays the most important role. Finally, making use of the disaggregated fiscal data series, we examine which fiscal components drive the electoral effects on budget deficits.

Our results are as follows. First, we find that the degree to which voters are informed about incumbents' fiscal policy conduct is the most important conditioning factor for PBCs amongst those examined in this paper. Next, a deeper investigation of voters' informedness suggests that it is the degree of media freedom that is critical. Specifically, we provide robust evidence that when media freedom is low, and thus when the information content is possibly influenced by a government, the electoral effect on budget deficits is large, even when the other conditioning factors are controlled for. This result can be related to rational opportunistic models that highlight informational asymmetry between governments and voters to explain electoral budget cycles. That is, media freedom, by helping voters to distinguish between competence and electioneering, may make it unnecessary for incumbents to create political budget cycles. Also, the result provides a way to relate different conditioning factors for PBCs, including 
fiscal transparency and the maturity of democracy, both of which are closely associated with media freedom. Last but not least, we find that when an incumbent government engineers an election-year rise in budget deficits under low media freedom, it does so primarily by increasing current (but not capital) expenditures. This is consistent with Rogoff (1990), who suggested that immediately visible current expenditure would be more adequate to signal the incumbent's competence than capital expenditure which frequently takes long to materialize.

The paper is organized as follows. Section 2 presents the literature review, highlighting various conditioning factors for PBCs investigated previously. Section 3 describes the dataset, Section 4 explains the empirical methodology, and the empirical results are presented in Section 5. Finally, Section 6 discusses the results and provides concluding remarks.

\section{Elections and opportunistic fiscal policy conduct: a literature review}

Elections are the most important mechanism to hold elected politicians accountable for their policy choices. Based on the idea that all politicians want to secure re-election, Nordhaus (1975) and Tufte (1978) pioneered the literature on political business cycles. They posit that, before elections, politicians adopt opportunistic expansionary fiscal or monetary policies to woo voters, and increase their popularity. These classical studies assume voter myopia and an exploitable expectations-augmented Phillips curve. Therefore, macroeconomic policies could have real effects over extended periods of time. Associated with the political cycle, an economic cycle would emerge, with unemployment decreasing before elections. After the election, the victor would adopt anti-inflationary measures that would raise unemployment again. In the long run, politicians' opportunistic measures would increase average inflation, without generating gains in the real economy.

The rational expectations revolution led to criticisms to the classical models of political business cycles, requiring their reformulation. The hypothesis that voters could be systematically fooled by 
politicians, even though they could easily foresee upcoming elections, became no longer tenable. In their seminal paper, Rogoff and Sibert (1988) demonstrate that an electoral budgetary cycle can still occur when economic agents are rational if voters have less information than those who shape policy. Given the asymmetry of information about the elected officials' level of competence, the latter strategically interact with competing candidates for office and with the electorate. Incumbent politicians engage in opportunistic expansionary fiscal policies before elections to signal their competence and increase their chances of re-election. This is accomplished by reducing taxes (immediately visible to the electorate) financed through seigniorage (observable with a lag), thus generating a budget cycle. Subsequently, Rogoff (1990) extends the analysis to pre-electoral manipulation of the composition of public spending, suggesting that opportunistic incumbents signal their competence to the electorate by shifting spending towards (immediately observed) consumption expenditure and away from investment expenditure (visible only after the election). Following these contributions, several studies empirically examine the possible occurrence of political budget cycles, highlighting circumstances under which incumbents conduct fiscal manipulation to increase re-election prospects. In what follows, we review the literature, organizing the conditioning factors into those affecting: 1) the readiness and incentives of incumbents to behave opportunistically; and 2) the capacity of opportunistic behavior to generate additional votes. ${ }^{1}$

\subsection{Factors affecting the readiness and incentives of politicians to act opportunistically}

For incumbents to manipulate fiscal policies, certain conditions need to be satisfied. One important condition is the predictability of the timing of elections. Some studies, using panels of countries, suggest that PBCs are more prevalent in samples including only predetermined elections; that is, elections held in the last year of a constitutionally fixed term for the legislature or executive (e.g., Shi and Svensson, 2006,

\footnotetext{
${ }^{1}$ For recent surveys on conditional budget cycles, see Dubois (2016), de Haan and Klomp (2013), and Veiga (2010).
} 
Vergne, 2009, and Efthyvoulou, 2012). ${ }^{2}$ The fragmentation of the government appears to be another key factor, affecting the ability of politicians to implement their most preferred policies. Regarding this point, Chang (2008) finds that, in OECD countries, fiscal policy manipulation during elections is constrained when policymaking power is dispersed among multiple veto players. In the same vein, Persson and Tabellini (2003) justify their finding that pre-election tax cuts are larger in parliamentary regimes than in presidential regimes with the argument that the latter regimes tend to have more decision makers with proposal and veto rights than the former. While in many presidential regimes, both the president and the legislature must approve the budget, in parliamentary regimes frequently the same majority controls the executive and approves the budget, and is thus better able to fine tune fiscal policy to electoral concerns (Persson and Tabellini, 2003: p. 206).

Turning to factors affecting incumbents' incentives to generate PBCs, Efthyvoulou (2012), using data for EU member countries from 1997 to 2008, emphasizes the importance of electoral competitiveness on politicians' incentives to generate PBCs. ${ }^{3,4}$ Changes in ideology may also affect politicians' incentives to engage in PBCs. Alesina and Tabbellini (1990) indicate that spending and deficits increase before elections when politicians expect to be replaced by an opponent with a different ideology, in order to limit the options of the newly elected candidate. ${ }^{5}$ Additionally, the level of rents extracted

\footnotetext{
${ }^{2}$ When the incumbent government can set the timing of elections, the analysis of PBCs becomes more complicated, since there are more options for electioneering. That is, politicians may choose the right time to call for elections instead of manipulating fiscal policy. We account for this possibility in the empirical analysis by estimating separate coefficients for pre-determined and early (potentially endogenous) elections, and by performing estimations for a restricted sample including only pre-determined elections. According to the literature mentioned above, stronger results for PBCs are expected when elections are pre-determined than when the electoral timing is uncertain.

${ }^{3}$ This factor was already a focus of the political business cycle literature starting in the 1970s. For instance, Frey and Schneider (1978a, 1978b) argue that when the election is competitive and incumbents are in danger of losing, they have a larger incentive to adopt expansionary policies before elections to stimulate the economy.

${ }^{4}$ At the local government level in Portugal, Aidt et al. (2011) take into account the interaction between the magnitude of the opportunistic distortion and the margin of victory, and show that incumbents behave more opportunistically when they expect elections to be more competitive.

${ }^{5}$ Partisan cycles were described by Hibbs (1977). For a survey of the impact of ideology on categories of public spending and revenues, see Franzese (2002).
} 
while in office is likely to influence the incentives to remain in power and thus the incentive for incumbents to engage in electoral fiscal manipulations. In this regard, Shi and Svensson (2006) argue that one of the reasons for PBCs to be larger in developing countries is that incumbent politicians gain more private benefits when in power than those in developed countries.

Finally, Persson and Tabellini (2003: section 8.5) shed light on the role of electoral rules (single versus multiple-district elections) in shaping incentives to engender PBCs. Based on Persson and Tabellini's (2000) career-concerns model, where individual accountability is stronger under majoritarian elections than in proportional elections, ${ }^{6}$ they argue that the former generate greater incentives to create tax and spending fluctuations around elections. Regarding effects on the composition of electoral spending manipulations, Persson and Tabellini predict stronger incentives for the adoption of broad policy programs to woo the voters, such as welfare-state spending, under proportional electoral rules. ${ }^{7}$ Using a panel of 60 countries, Persson and Tabellini (2003) found effects of constitutional provisions on the existence and composition of electoral cycles in fiscal policy. They claim that tax cuts in electoral years are universal, but only in presidential regimes they are reversed immediately after the elections. Second, only incumbents in majoritarian countries reduce spending during election years. Third, expansions in welfare spending in the proximity of elections are only observed in proportional democracies. Along the same lines, Chang (2008), focusing on OECD countries, shows that incumbents increase social welfare spending before elections under proportional representation, while they raise district-specific spending (including

\footnotetext{
${ }^{6}$ Furthermore, in proportional systems, incentives for good individual performance by a politician may be diluted because citizens vote on a list and, consequently, elections are a less powerful tool to discipline policymakers. Working with a panel of countries, Shelton (2014) confirms Persson and Tabelini's prediction that electoral budget cycles are stronger under majoritarian rules. He also claims, and finds evidence, that a strong party system mitigates the electoral budget cycles more in countries with majoritarian electoral systems than in those with proportional rules.

${ }^{7}$ Under proportional electoral systems incumbents need to please one half of the voters, while in majoritarian systems they only need to please roughly one fourth (half the voters in half the districts). Therefore, majoritarian electoral rules induce politicians to target spending to smaller (geographical) groups.
} 
infrastructure investments such as construction and transport spending) under single-member district systems.

\subsection{Factors affecting the capacity of opportunistic behavior to generate additional votes}

While favorable conditions may render incumbents' fiscal manipulations possible, it also matters whether such actions are likely to yield additional votes. Both Rogoff and Sibert's (1988) and Rogoff's (1990) seminal models of rational PBCs rely on temporary information asymmetries regarding the incumbent leader's competence to explain PBCs. Opportunistic incumbents use fiscal policy to signal competence. According to Rogoff (1990: p. 22), "PBCs may be a socially efficient mechanism for diffusing up-to-date information about the incumbent's administrative competence".

Shi and Svensson (2006) and Alt and Lassen (2006a) follow a different theoretical approach to explain PBCs. They develop career-concerns models that do not involve signaling, but rather emphasize moral hazard problems. They argue that, under asymmetric information, all incumbents (not only competent ones) have an incentive to create PBCs if they have the power to do so. According to Shi and Svensson (2006), PBCs are larger in developing than in developed countries because in the latter there is a larger share of informed voters, making fiscal policy manipulations less effective. In a similar vein, Alt and Lassen (2006a) emphasize that fiscal policy transparency makes it harder to hide manipulations in fiscal policy, and therefore, diminishes the incidence of PBCs. Alt and Lassen (2006a and 2006b) claim that fiscal electoral cycles are not confined to, or driven by, weaker and newer democracies, as argued by Brender and Drazen (2005). They show that, even among advanced democracies, opportunistic electoral cycles appear where budget institutions are less transparent. Thus, voter information is a crucial factor determining the magnitude of fiscal manipulations.

Several studies empirically analysed the effects of voter information and media freedom on PBCs. Using regional monthly panel data for the first decade of democracy in Russia, Akhmedov and Zhuravskaya 
(2004) find that the magnitude of the budget cycle decreases with government transparency, media freedom, and voter awareness. Focusing on American states, Alt and Rose (2007) present evidence indicating that electoral cycles in spending are larger under low transparency and low newspaper circulation, a proxy for media penetration. On a sample of 42 developing countries, Vergne (2009) confirms that a greater share of informed voters leads to smaller political budgetary cycles. Like Shi and Svensson (2006), they proxy the share of informed voters with a variable that results from the multiplication of radios per capita by a measure of freedom of broadcasting. Finally, Shelton (2014) also finds that budget transparency and media freedom are important in curbing electoral budget cycles in a panel dataset of 93 democracies.

Brender and Drazen (2005) highlight the importance of the maturity of democracy, showing that PBCs are more important in new, rather than in established, democracies. This is presumably because, when voters lack experience with electoral manipulations, or lack the information needed to evaluate them, opportunistic measures will gain their support more effectively. Following this argument, Brender and Drazen (2013), using a panel of 71 democracies, present evidence for election-year effects on the composition, rather than on the level, of expenditure under established democracies. ${ }^{8}$ In line with their results, Katsimi and Sarantides (2012), focusing on a panel of 19 OECD countries (established democracies), show that for countries with predetermined electoral periods, current expenditure increases at the expense of capital expenditure, while there is no evidence of an increase in total expenditure or the deficit. ${ }^{9}$

\footnotetext{
${ }^{8}$ They also examine post-election development in the composition of expenditures. Using an index of changes in the composition of central government expenditures, they conclude that leadership changes do not influence the composition of expenditures in the first two years of the term, but they result in greater compositional changes over a four-year period, particularly in developed countries.

${ }^{9}$ However, they suggest that total revenue may decrease, driven by a fall in direct taxation.
} 


\subsection{This paper's contribution}

Although a few studies helped disentangle some of the conditioning factors for PBCs, ${ }^{10}$ none has systematically investigated the relative importance of a number of conditions reviewed above. This paper helps fill this gap in the literature, revealing that voters' informedness is the critical condition. Moving a step further, we show that what makes this condition critical is primarily the degree of media freedom, rather than the mere availability of means of information (radios, newspapers, TVs and access to the internet). As indicated in the introduction, this result has an implication on the theoretical literature of PBCs, particularly on rational opportunistic models assuming asymmetric information about incumbent's competence. To emphasize, our investigation on the relative importance of the conditioning factors of PBCs, including media freedom, is facilitated by our unique dataset which covers both developed and developing countries for a long time period and thus offers a comprehensive platform to explore this issue. ${ }^{11}$ Moreover, the fact that the dataset respects the government budget constraint for all the observations $^{12}$ and disaggregates total spending (in particular) enables us to examine which spending component may drive the occurrence of budget cycles under low media freedom, the condition critically indicative of PBCs. We believe that the finding that the current spending component, not the capital component, drives PBCs adds to the literature, by suggesting how opportunistic incumbents may manipulate fiscal policies to stay in office under low media freedom.

\footnotetext{
${ }^{10}$ For example, Alt and Lassen (2006b) discuss the importance of fiscal transparency relative to media ownership.

${ }^{11}$ A comparison of country panel databases used in recent studies of PBC is provided in Table A1 (Section 1) of the Online Appendix (http://www1.eeg.uminho.pt/economia/fjveiga/papers/JELS 2016168 Online-Appendix.pdf).

12 Since we obtain deficits by adding up current and capital expenditure, and then subtracting total revenue, by definition, the budget constraint is respected for all the observations in the dataset.
} 


\section{The dataset}

In what follows, we describe the assembly of a panel dataset covering central governments' expenditure and revenue series, elections and other political variables, and other control variables (including macroeconomic series), for developed and developing countries, over the period 1975-2010. ${ }^{13}$

We assemble a public finance dataset at the central government level, based on the IMF's Government Finance Statistics (GFS) yearbook. A key innovation of this dataset is to bridge major methodological changes in the GFS manual (GFSM). These changes were implemented from the mid1990s to the early-2000s, with the introduction of GFSM2001, which replaced the older GFSM1986. In essence, we retrieve historical spending and revenue data available for all countries that have reported data to the GFS yearbook for the $1975-2010$ period, and then assemble comparable data series for disaggregated expenditure and revenue, referring to Wickens (2002), who details the methodological differences between the two manuals. In particular, we create comparable disaggregated public spending series which consist of current and capital components. Then, ensuring that both of these components, together with comparable total revenue series, are available in a given year for a country, we calculate the budget deficit as a difference between total spending (a sum of current and capital components) and

\footnotetext{
${ }^{13}$ Descriptive statistics for the variables used in the estimations are reported in Table A2 (Section 2) of the Online Appendix. The reference dataset consists of 69 countries. Although we gathered data for more than 100 countries, 1) creating comparable fiscal data series over the period (explained below), 2) focusing on the case in which the government budget constraint is respected, and 3) ensuring that all the information on the relevant conditioning factors for PBCs, including the measure of media freedom (clarified below) is available, all bring down the number of countries. The 69 countries are: Argentina, Australia, Austria, Bahamas, Barbados, Belgium, Belize, Bolivia, Bulgaria, Burundi, Canada, Chile, Colombia, Costa Rica, Croatia, Cyprus, Czech Republic, Denmark, Dominican Republic, El Salvador, Estonia, Fiji, Finland, France, Germany, Greece, Grenada, Guatemala, Hungary, Iceland, India, Indonesia, Ireland, Israel, Italy, Japan, Korea, Latvia, Lithuania, Luxembourg, Malta, Mauritius, Mexico, Moldova, Mongolia, Netherlands, New Zealand, Nicaragua, Norway, Panama, Papua New Guinea, Paraguay, Peru, Philippines, Poland, Portugal, Romania, Slovak Republic, Slovenia, Spain, Sri Lanka, Sweden, Thailand, Turkey, Ukraine, United Kingdom, United States, Uruguay, and Vanuatu.
} 
total revenue. ${ }^{14}$ Thus, with the data series respecting the government budget constraint, we can examine which spending item may drive the possible creation of PBCs.

Turning to political variables, our first task is to distinguish democratic and non-democratic regimes across the countries in the sample. Despite the widespread use of the variable POLITY2 from the Polity IV database to identify democracies, it has recently come under considerable criticism, as it attributes similar scores in quite different situations. Vreeland (2008) calls special attention to the problems of POLITY2 when dealing with anocracies, that is, cases in the borderline between democracies and dictatorships (values of POLITY2 close to zero). Cheibub, Gandhi and Vreeland (2010), among others, argue that using a specific score of POLITY2 to identify democracies may not be the best choice, as some of its components are poorly conceptualized and its scoring of democracy, ranging from +10 (strongly democratic) to -10 (strongly autocratic), is not precise. Given the problems with POLITY2, we use instead the democracy dummy variable (DD) of Cheibub, et al. (2010). We only consider democracies in our dataset $(D D=1)$. In the case of new democracies, the year of the switch from dictatorship to democracy is used as the reference for the beginning of democracy in the respective country. The number of elections/years from then on determines when a new democracy becomes an established one (as in Brender and Drazen, 2005). ${ }^{15}$

Data on the elections, since 1975, for the chief executive are from the 2012 version of the Database of Political Institutions - DPI (see Beck et al., 2001). Presidential elections are considered for

\footnotetext{
${ }^{14}$ A more detailed description of the construction of the fiscal dataset is provided in Section 3 of the Online Appendix. Previous studies covering both developed and developing countries essentially used data based on GFSM1986, thus covering periods between the 1970 s and the late 1990 s or early 2000 s. One example is Vergne (2009), who covers the period 1975-2001. Brender and Drazen (2013) is an exception, who also bridge the GFSM1986 and GFSM2001. However, their dataset only considers the functional classification of spending, while ours covers the economic classification of spending and revenue.

${ }^{15}$ For the precise definition of established/new democracies, see Section 5. As a robustness test, we also created a democracy dummy variable which takes the value of 1 when POLITY2 is greater or equal to zero (as in Brender and Drazen, 2013). We report that the identification of established and new democracies using POLITY2 and the democracy dummy of Cheibub et al. (2010) leads to similar results.
} 
presidential systems (SYSTEM=0), while legislative elections are used for parliamentary systems and other systems in which the president is not elected by universal suffrage. We construct an election-year dummy variable (Election_year) which takes the value of one in the election year, and equals zero otherwise. ${ }^{16}$ Since in several countries (e.g. Canada, UK, and USA) the fiscal year is not coincident with the calendar year, the election-year variable is adjusted taking into account the fiscal year and the month in which the elections took place. ${ }^{17}$

Data from the DPI is also used to distinguish proportional representation electoral systems from majoritarian ones and presidential systems from parliamentary ones. Several other variables, related to ideology, shares of votes/seats, fractionalization, polarization, checks and balances, etc., are also obtained from the DPI. Other political variables used include the Henisz (2000) index of political constraints and an institutional index built along the lines of that of Shi and Svensson (2006) that uses data from the International Country Risk Guide.

We include in all our estimations a set of control variables that might affect the behavior and composition of public finances, including those used in Brender and Drazen (2005) and also a set of decade dummies:

- Log of GDP per capita at 2005 constant US dollars: obtained from the World Development Indicators - WDI (World Bank). This variable controls for the income level of the countries.

- Trade (\% GDP): sum of exports and imports as a percentage of GDP (also from the WDI). This variable controls for the effects of trade openness on public finances.

\footnotetext{
${ }^{16}$ The variables EXELEC and LEGELEC from DPI were used to determine the year in which each election occurred.

${ }^{17}$ For example, if the fiscal year starts in April and the elections take place in March of year $t$, then the relevant fiscal year is that of year $t-1$. Thus, Election_year will equal 1 in $t-1$ instead of $t$. Information on the fiscal year of each country was obtained from the IMF's GFS Yearbook, while the variables DATEEXE, and DATELEG, from DPI, were used to identify the month of each election.
} 
- Output gap: logarithmic difference between real GDP and its trend (obtained using the HodrickPrescott filter). Data for the real GDP is from the World Economic Outlook (IMF). The output gap controls for the effects of business cycles on public finances.

- Percentages of the population below 15 and above 65 years old: these demographic variables were obtained from the WDI and control for the effects of demography on public finances.

- $1970 s, 1980$ s, 1990s, 2000s: decade dummy variables used to control for the passage of time. ${ }^{18}$

\section{Empirical analysis}

In this section, we first present the baseline model and clarify how we compare the relative importance of political considerations as conditioning factors for political budget cycles. Then, we discuss the estimation methods, highlighting the way we address the innate endogeneity issues within dynamic panel models.

\subsection{Empirical models}

The point of departure of our empirical analysis is a baseline model which is commonly used in the literature to test for unconditional electoral effects on fiscal variables:

$$
f_{i t}=\sum_{j=1}^{p} \alpha_{j} f_{i, t-j}+\beta E L Y_{i t}+\boldsymbol{X}^{\prime}{ }_{i t} \boldsymbol{\delta}+\mu_{i}+\varepsilon_{i t} \quad i=1, \ldots, N \quad t=1, \ldots, T_{i}
$$

\footnotetext{
${ }^{18}$ Although we also considered the option of using year dummy variables, the problem is that, with 36 years of observations, their inclusion greatly increases the number of instruments in system-GMM estimations. In fact, for those estimations where a lower number of countries is available, the number of instruments is sometimes higher than the number of countries, which is likely to make the instrument matrix invalid. Thus, although the results are very similar in general, we preferred to take time effects into consideration through the inclusion of decade dummy variables (leaving out the dummy for the 2000s). The results are also very similar when we use instead a quadratic time trend. These results are not shown here, but are available from the authors upon request.
} 
where $f_{i t}$ is a fiscal variable in country $i$ in year $t$ and $p$ is its number of lags included in the model, $E L Y_{i t}$ is an electoral variable, ${ }^{19} \boldsymbol{X}_{i t}$ is a vector of control variables (including the decade dummies), $\mu_{i}$ is the effect of country $i, \varepsilon_{i t}$ is the error term, and $\alpha, \beta$, and $\delta$ are parameters or vectors of parameters to be estimated.

As summarized in the literature review, several factors may condition the occurrence of political budget cycles. However, while a number of studies present empirical results accounting for one or more of these factors, little is known about their relative importance as a driver of PBCs. To address this, we compare the importance of these conditions by taking two complementary approaches. To explain the first, we introduce the equation which interacts the election year variables with different political attributes:

$$
\begin{gathered}
f_{i t}=\sum_{j=1}^{p} \alpha_{j} f_{i, t-j}+\beta_{1}\left(E L Y_{i t} * D_{i t}\right)+\beta_{2}\left(E L Y_{i t} *\left(1-D_{i t}\right)\right)+\emptyset D_{i t}+\boldsymbol{X}_{i t}^{\prime} \boldsymbol{\delta}+\mu_{i}+\varepsilon_{i t} \\
i=1, \ldots, N \quad t=1, \ldots, T_{i}
\end{gathered}
$$

where $D_{i t}$ is a dummy variable that proxies a specific attribute, and the remaining variables and parameters are as defined in equation (1). We then estimate equation (2) for different subsamples characterized by specific political attributes. The idea is to determine if any of the conditioning factors (e.g., voters' informedness) produce significant electoral effects on fiscal variables, even when other drivers of PBCs are controlled for (e.g., the predictability of the timing of elections). The second, more direct, approach is to examine the explanatory power of each condition in a fully-nested specification based on the entire sample. That is, after identifying political attributes which drive PBCs individually, we

\footnotetext{
${ }^{19}$ We also estimated models including pre- and post-electoral dummy variables, in order to capture opportunistic effects that may happen in the year before elections, and post-electoral reversal of opportunistic policies. In general, only the election-year dummy variable is statistically significant. In models including just the dummies for the election and the post-election years, they generally have opposite signs (as expected), but only the election year dummy tends to be statistically significant (see Tables A7-A9 in Section 5 of the Online Appendix). The same happens when the three electoral dummies are included simultaneously. Given the absence of statistical significance of the pre- and post-electoral dummy variables, we adopted the more parsimonious specification which only includes the election year dummy variable.
} 
include the election-year variable together with its interactions with all these conditioning factors simultaneously in the same estimation:

$$
\begin{gathered}
f_{i t}=\sum_{j=1}^{p} \alpha_{j} f_{i, t-j}+\beta E L Y_{i t}+\sum_{k=1}^{m}\left[\gamma_{k}\left(E L Y_{i t} * D_{k i t}\right)+\emptyset_{k} D_{k i t}\right]+\boldsymbol{X}^{\prime}{ }_{i t} \boldsymbol{\delta}+\mu_{i}+\varepsilon_{i t} \\
i=1, \ldots, N \quad t=1, \ldots, T_{i}
\end{gathered}
$$

where $m$ is the number of conditioning factors included. The variables are defined as in equations (1) and (2).

\subsection{Empirical methodology}

The estimation of the above linear dynamic panel data models using OLS produces biased coefficients, since the lagged dependent variable is endogenous with respect to the country effects. OLS estimation will be inconsistent, even assuming fixed or random effects, because the lagged dependent variable is correlated with the error term, even if the latter is not serially correlated (see Arellano and Bond, 1991). This bias becomes smaller as the number of periods increases. Given that our dataset covers a 36-year period, it would be safe to simply estimate a fixed effects model. However, our panel is unbalanced and the average number of observations per country in most regressions is considerable smaller. Thus, the fixed effects model may still suffer from dynamic panel bias.

Arellano and Bond (1991) developed a Generalized Method of Moments (difference-GMM) estimator that solves the problems mentioned above by taking first differences of the dynamic equations and instrumenting predetermined and endogenous variables with their available lags in levels. But, when taking first differences, the cross-sectional relationship between the dependent and explanatory variables is lost. Furthermore, as shown by Blundell and Bond (1998), lagged levels may be weak instruments for first-differences if the series are persistent. According to Arellano and Bover (1995), efficiency can be improved by adding the original equation in levels to the system, that is, by using the system-GMM 
estimator that combines the first-differenced and levels equations. Thus, in what follows, we use systemGMM, as well as fixed-effects estimators.

When estimating system-GMM models, we take account of the possibility that fiscal variables affect macroeconomic performance. ${ }^{20}$ Specifically, we treat GDP per capita, trade and the output gap as endogenous variables, while treating the lagged dependent variable as predetermined. However, when there are several endogenous variables in a model, the number of instruments can easily become very large, leading to over-fitting of the data which can bias t-statistics upwards. Thus, to avoid this problem (and having in mind the fact that more distant lags are usually weak instruments) we limit the lag length to that strictly necessary to have a valid instrument matrix. ${ }^{21}$ To report, since Hansen tests never reject the validity of the instrument matrix and second order autocorrelation is always rejected in the analyses below, there is evidence supporting the validity of our results. Furthermore, Difference-in-Hansen tests do not reject the validity of the subsets of instruments.

\section{$5 \quad$ Empirical results}

In what follows, we particularly compare the relative importance of the following five conditioning factors, for which evidence of PBCs are confirmed in the context of our sample: predetermined elections; close/disputed elections; low degree of voter information; new democracies; and proportional electoral systems. Specifically, in a preliminary analysis (not shown here for brevity; detailed in the Online

\footnotetext{
${ }^{20}$ When using fixed-effects estimators, we mitigate endogeneity/simultaneity problems by lagging all control variables (except for election-year dummies) by one period.

${ }^{21}$ The baseline specification uses the two periods lagged levels of the fiscal variables and of the other endogenous variables as instruments in the first-differenced equations and their once-lagged first-differences are used in the levels equation. The exogenous variables are used as their own instruments. The collapse option of the xtabond2 Stata command is used to avoid an excessive number of instruments. The lag structure is adjusted when the baseline specification mentioned above does not pass all Hansen and difference-in-Hansen tests.
} 
Appendix), we estimated our baseline model of equation (1), not only for the entire sample, ${ }^{22}$ but also for subsamples characterized by several different political attributes, and found evidence of PBCs under each of the above mentioned five conditions, in line with the previous literature. ${ }^{23}$ The following analysis, which examines their relative importance, focuses on the observations for which information on all of these conditions are available, corresponding to 884 observations from 69 countries. The corresponding dummy variables used in equations (2) and (3) are defined as (with $m=5$ in equation 3 ):

- Predetermined election: equals 1 when the elections are held in the last year of a constitutionally fixed term, and equals zero otherwise. (Not Predetermined election $=1$ - Predetermined election)

- Close election: equals 1 when the difference in vote shares between the major government party and opposition parties (or candidates, in presidential elections) is smaller than 10 percentage points, and equals zero otherwise. (Not Close election $=1-$ Close election)

- IMD High: equals 1 when the index of media diffusion (IMD), defined as in Shi and Svensson (2006), is higher than its sample median, and equals zero otherwise. (IMD Low = $1-$ IMD High). $I M D$ is a composite of the measures of media freedom and the extent of information diffusion. ${ }^{24}$

\footnotetext{
${ }^{22}$ The full results of system-GMM and fixed effects (FE) estimations for the entire sample are reported in Table A3 of Section 4 of the Online Appendix. There is evidence of election year increases in budget deficits and expenditures, and of decreases in revenues.

${ }^{23}$ These results, reported in Table A4 of the Online Appendix, confirm previous works such as Brender and Drazen (2005), Shi and Svensson (2006), Efthyvoulou (2012), and Persson and Tabellini (2003), which indicate that the predictability and competitiveness of elections, the share of informed voters, the maturity of democracy, and electoral rules are conditional factors affecting PBCs. Several additional tests, whose results, for brevity, are not reported, were also performed. First, we investigated if government fragmentation influences its ability to engender fiscal electoral cycles. Second, we used the Henisz (2000) index of political constraints as an indicator of the government's ability to generate PBC. Third, following Shi and Svenson (2006), we proxied the level of rents extracted while in power, using an institutional index constructed with indicators provided by the International Country Risk Guide (ICRG). Fourth, we analyzed whether electoral effects differ among developed/developing countries, and among strong/weak democracies. Fifth, following Alesina and Tabellini (1990), we examined whether changes in the ideology of the government influence the magnitude of opportunistic fiscal measures. Finally, the role of the system of government (Persson and Tabellini, 2000, 2003) in shaping PBCs was also examined. Although we often observed results consistent with these works in the context of our dataset, the results either lacked significance or robustness. These results are available from the authors upon request.

${ }^{24}$ Using the Freedom House data on the freedom of broadcast as a proxy for media freedom, we assign the classifications of Free, Partially Free and Not Free the numerical values of 2, 1 and 0, respectively (we use the general
} 
- Established democracy: takes the value of 1 after ten years have passed and four democratic elections have taken place in the country after it became a democracy, and equals 0 otherwise. ${ }^{25}$ (New democracy $=1-$ Established democracy).

- Proportional representation: takes the value of 1 for proportional representation electoral systems, and equals zero otherwise. Majoritarian $=1-$ Proportional representation. ${ }^{26}$

For brevity, the following tables highlight the coefficients and t-statistics for the key variables of interest (while Section 4 of the Online Appendix shows results on the other routinely-controlled variables in the context of the preliminary analysis). Further, again for brevity, the tables below do not report the results of diagnostic tests, including the above-mentioned tests checking the validity of system-GMM estimators. As mentioned above, the test results confirm their validity in the following analysis. ${ }^{27}$

The first row of Table 1 examines the role of the index of media diffusion (IMD) in PBCs in particular, using the interaction approach of equation (2). It shows that, regardless of the samples examined, deficits rise in election years when the IMD is low (below the sample median), but not when it is high (except for 1 out of the 10 estimations). Notice that the subsamples considered there (columns 3 to 10) are all characterized by political attributes which drive PBCs individually. Moreover, Wald tests reject the equality of coefficients in as many as 7 out of the 10 estimations, indicating that IMD tends to differentiate the electoral effects on deficits, even when the other relevant conditions are controlled for.

freedom of the press status after 2000 because no separate scores for freedom of broadcast and for printed press are available after that year). Then, the index of media diffusion (IMD) is obtained by multiplying this series by that of the number of radios per capita (taken from the Cross National Time Series database - CNTS) as a proxy for information diffusion. We define as high IMD the values above or equal to the sample median. This variable is defined for observations for countries that are democracies and for which data on the budget deficit is available.

${ }^{25}$ As in Brender and Drazen (2013), democracies are classified as new during the first four democratic elections, and become established thereafter. We also require that at least 10 years have passed since the country became a democracy. Changing this threshold to 15 years does not change the results.

${ }^{26}$ Several countries have mixed systems, under which some of the legislators are elected according to proportional representation rules, while others are elected according to majoritarian rules. In these cases, the electoral system was classified as proportional if the majority of the legislators in the lower house of the parliament is elected under proportional representation rules (when the variable HOUSESYS of DPI equals zero).

${ }^{27}$ All the detailed estimation results, including the diagnostic tests, are available from the authors upon request. 
While the same exercise is repeated for other four conditions (i.e., predetermined vs non-predetermined elections; close vs not-close elections; new vs established democracies; proportional vs majoritarian electoral rules), we report that the importance of voters' information clearly stands out. ${ }^{28}$

\section{[Table 1]}

The analysis then goes one step further. Specifically, acknowledging that the IMD is a composite of media freedom and the prevalence of devices for disseminating information (proxied above by the freedom of broadcast and the number of radios per capita, respectively), we investigate which of these components may make the IMD such a critical factor. This exercise is important, because these two concepts, though seemingly correlated, reflect different aspects of voters' information. For example, even when the state controls news content of media outlets (e.g., by exerting pressure on them) and voters' information is thus potentially biased, it does not mean that voters do not have means to receive the information.

The following rows of Table 1 report the results of estimations of equation (2) for the components of IMD. The second row examines the role of media freedom. The status of the freedom of broadcast, which takes the discrete values of 0,1 , and 2 , is inconvenient to use in classifying media freedom into the high and low-levels (particularly when we wish to divide observations into equal-sized groups). Instead, we use the overall Freedom of The Press (FOTP) scores of Freedom House, which are based on freedom of both broadcast and print, and take values in the region between 0 and $100 .{ }^{29}$ The results clearly show

\footnotetext{
${ }^{28}$ See Table A5 of the Online Appendix. The results of Wald tests are considerably stronger for voters' information (IMD) than for the other conditioning factors of PBCs in differentiating the electoral effects in different sub-samples.

${ }^{29}$ The original FOTP scores are in decreasing order of freedom, that is, higher values correspond to lower freedom. In order to make the scores and their coefficients in the estimations more intuitive, we adjust the values, so that 0 corresponds to no freedom, while 100 to complete freedom. The ranges of each status are then: 0-30, Not Free; 3160, Partially Free; and 61-100, Free. The FOTP scores (from 0 to 100) are available since 1993. From 1979 to 1992 , only the broadcast and print freedom statuses (Free, Partially Free, and Not Free) are available. Using the scores of 1993 and the respective statuses, we attribute the same score backwards until 1979 if the status does not change during that period. When the status changes, we attribute the closest value of the range of values of the new status. For example, if the 1993 score corresponds to a status of Partially Free, but from 1979 to 1985 the status was Not
} 
that PBCs occur when media freedom is low (below the sample median), with the Wald test rejecting the equality of the coefficients on the interaction variables in 9 out of 10 estimations (and the p-value in the only exception is just 0.14). The indication is thus that media freedom, a component of the IMD, is a critical conditioning factor for PBCs.

Next, when highlighting radios per capita as a proxy for information diffusion (third row), the interaction of the election year with radios per capita below the sample median is always statistically significant, while the interaction with radios per capita above (or equal to) the median is, at best, marginally significant. However, given that Wald tests only reject the equality of the coefficients in 4 out of 10 estimations, the results are weaker when considering means of information diffusion alone than when media freedom is taken into account. What about other means of information diffusion? To address this question, we create a broader indicator of the means of information diffusion, taking the average of radios, TVs, and newspaper circulation per capita. The results in the fourth row of Table 1 show that the Wald tests only reject the equality of the coefficients for the interaction variables in 2 out of 10 estimations, suggesting that the prevalence of information devices itself may not be a key driver of PBCs.

Although radios, TVs and newspapers were certainly the main means of information diffusion in the $20^{\text {th }}$ century, the internet plays a key role today. Thus, it is possible that access to the internet is an important conditional factor of PBCs. We test this hypothesis in the last row of Table 1, using data on internet users per capita (from the WDI). The results clearly indicate that election year increases in deficits tend to occur when access to the internet is low (below the median of the respective year), but not when it is high. Wald tests reject the equality of the coefficients on the interaction variables in 6 out of 10 estimations, which is a slightly stronger result than for the other information devices, but weaker than for

Free, we attribute the score of 1993 backward until 1986, and then assign a score of 30 (the closest value of the range of the new status) from 1979 to 1985. 
the IMD or media freedom. ${ }^{30}$ Although in principle the internet facilitates access to information, governments may exert control over the internet by filtering its content. Internet censorship is present in several countries for a range of social, political, and security reasons, blocking materials such as information related to free expression and comments insulting the state (Warf, 2012). Overall, the general indication of the results of Table 1 is that media freedom is a more important conditioning factor for PBCs than the means of information diffusion.

Table 2 reports the results based on a complementary analysis. Specifically, columns 1 and 2, focusing on the media freedom component of the IMD, present the estimation results of equation (3), which controls for the effects of other conditioning factors simultaneously. ${ }^{31}$ The interaction of the dummy variable for low media freedom (based on the overall FOTP scores) with the election year is statistically significant in both system-GMM and fixed effects estimations (columns 1 and 2, respectively), while among those for the other conditioning factors, only that for proportional electoral systems is statistically significant in column 2. Regarding the marginal effects of the election year, they are significantly different across the values of the media freedom dummy (the p-values are 0.06 and 0.03 ), suggesting that the electoral effects on budget deficits are higher when media freedom is low than when it is high. Although the Wald test marginally rejects the equality of marginal effects for proportional electoral systems in column 2, the same result does not hold in column 1.

\section{[Table 2]}

Moreover, in columns 3 and 4, we directly compare the relative importance of different aspects of voters' information, while still controlling for all the other conditioning factors. To do so, we add dummy

\footnotetext{
${ }^{30}$ Since data on internet access is practically non-existent before the mid-1990s, the use of this indicator implies the loss of around one third of the observations (from 884 to 576 when considering all elections), and of about half of the sample period. For this reason, we do not use this variable in the following tables.

${ }^{31}$ A similar exercise was done for the index of media diffusion (IMD) in columns 3 and 4 of Table A6 of the Online Appendix.
} 
variables for the means of information diffusion (for values below their sample medians) simultaneously, together with their interaction terms with the election year dummies. Observe that the coefficients on the interactions between the media freedom dummy and the election year dummy are always statistically significant, while the remaining interactions containing different information variables are never statistically significant. The message is similar even when we rigorously compare the marginal electoral effects across the different values of dummy variables for all the different information variables: only media freedom robustly differentiates the electoral effects on budget deficits. ${ }^{32}$ Overall, together with the results shown in Table 1, our conclusion is that amongst all the political attributes examined, media freedom, a component of IMD, stands out as the crucial conditioning factor for PBCs.

Next, having identified the crucial role of media freedom for the occurrence of PBCs, we now take advantage of the richness of our dataset to analyze which changes in fiscal components may drive the election year rise in budget deficits. Table 3, based on equation (2), presents the results both for the entire sample and for a sub-sample in which election dates are predetermined (for robustness check). ${ }^{33}$ Columns 1 to 3 show the results for expenditures, columns 4 and 5 for revenues, and column 6 reproduces the results for the budget deficit reported in Table 1. The results show that election-year increases in total and in current expenditures occur under low media freedom, with an indication of even sharper results

\footnotetext{
${ }^{32}$ Although radios per capita and proportional electoral systems also seem to differentiate the electoral effects on budget deficits in the fixed effects estimation of column 4, the same does not apply to the system-GMM estimation of column 3 , where media freedom is the only statistically significant differentiating factor.

${ }^{33}$ As mentioned above, the possibility of holding early election adds complexity to PBC models, as the election date becomes endogenous if the incumbent government is able to set it. In our sample, there were 48 elections (out of 202) which occurred before the last year of the constitutionally fixed term. While some may have been opportunistically anticipated by incumbent governments, others were due to no confidence votes in parliament, the end of government coalitions, or dissolutions of parliament by the head of state. Additionally, in many countries, the government is not able to call for early elections. Thus, of the 48 early elections, only a few may have been provoked by electoral timing of the incumbent. Exactly identifying those cases would involve a thorough analysis of each of the 48 early elections. Furthermore, although the analysis of the determinants of electoral timing is an interesting research topic, it is beyond the scope of the present study. Thus, as a robustness check of our results, we also estimate the models for a sample that only includes pre-determined elections (in which the issue of electoral timing is not present).
} 
for predetermined elections, for which the Wald tests always reject the equality of the coefficients of the interaction variables. When media freedom is high, there is no robust evidence of election year deficits, or of changes in total expenditure or revenue, although the results indicate that there may be changes in the composition of spending. Concretely, current expenditures seem to increase and capital expenditures are reduced in election years under high media freedom.

Given that capital spending generally takes longer to materialize, Rogoff (1990) suggest that it may not be as suitable to signal the incumbent's competence as immediately-observed current spending. Additionally, capital spending is often associated with medium to long-term investment projects whose completion may be hard to coordinate with election dates, creating the risk of having incomplete projects at election time, which could signal low competence of the incumbent (Vergne, 2009). Our results are also consistent with the strategic reallocation of budgetary expenditures toward more visible or voter-friendly spending, as found in the studies of Veiga and Veiga (2007) and Drazen and Eslava (2010), for Portuguese and Columbian municipalities, respectively.

\section{[Table 3]}

The election year changes in the composition of expenditures and revenues were further investigated by performing estimations for separate samples of low and high media freedom, i.e., below and above (or equal to) the sample median, respectively. The results for the low media freedom sample are shown in Table 4, providing clear evidence that the observed election-year rise in deficits is driven by a rise in current expenditures, regardless of the estimation method or whether we consider all elections or only predetermined ones. As a supplementary result, we find weak evidence that the election-year rise in current expenditures may be associated with increases in the compensation of employees. Further, although the results regarding total revenues and taxes are weak, there is a stronger indication that 
personal income taxes are reduced in election years. ${ }^{34}$ Increases in the compensation of employees please public servants and their families, who sometimes account for a considerable percentage of voters, and reductions in personal income taxes please voters in general. ${ }^{35}$ Thus, these are clearly voter-friendly policies aimed at increasing the incumbent governments' chances of reelection. Finally, the results of the estimations on a sample of high media freedom do not present robust evidence of PBCs, consistent with the results of Table 3, although there is again some indication of expenditure reallocation. ${ }^{36}$

\section{[Table 4]}

\section{Discussion and Conclusion}

Why does the degree of media freedom play a key role in determining electoral patterns in budget deficits? The literature on the role of mass media in shaping economic and political outcomes provides some valuable clues to answer this question. For example, Besley and Prat (2006)'s theoretical model of democratic politics illustrates that media capture makes it less likely for bad politicians to be identified and thus replaced. This indicates that in the context of PBCs, low media freedom may prompt incumbent governments to manipulate fiscal policies to increase their re-election prospects. Also, Leeson (2008)'s finding that media capture lowers voters' political knowledge and participation suggests another possible channel thorough which media freedom affects electoral budget cycles. That is, to the extent that low media freedom produces politically ignorant and inactive individuals, politicians tend to be free from accountability to voters, and may thus use fiscal policies opportunistically.

\footnotetext{
${ }^{34}$ The results for other subcomponents of expenditures and revenues are not robust, eventually because the number of available observations tends to be considerably smaller for the subcomponents than for the totals.

${ }^{35}$ Although reductions in other taxes (consumption, property, etc.) might also please voters, personal income taxes are arguably the most salient to the generality of voters. Thus, reducing this type of taxes seems to be a more effective strategy to win votes than reducing other types of taxes.

${ }^{36}$ For brevity, these results are not reported in the paper, but they are available upon request.
} 
Our study contributes to the literature in several ways. First, it provides a micro-foundation for the Rogoff and Sibert (1988) seminal work on political budget cycles, and for other PBC models based on incomplete information regarding the incumbent's competence. When media freedom is high, more accurate information is conveyed, making it easier for voters to observe the true level of competence of the incumbent. By reducing information asymmetries between policy-makers and the electorate, media freedom diminishes politicians' incentives to signal competence, mitigating the political budget cycles.

Second, our results on media freedom and PBCs offer one possible way of relating existing theories of PBCs. That is, since several conditioning factors indicated in the previous literature are correlated with media freedom, it may provide a crucial link between those factors. For example, Djankov et al. (2003) show that state ownership of media is higher in more autocratic countries. This result suggests that media freedom tends to be lower in new democracies (which were autocratic until relatively recently) than in established democracies. Also, fiscal transparency, proposed by Alt and Lassen (2006b) as a key conditioning factor of PBCs, is closely linked to media freedom, as illustrated by their definition (p. 531): "fiscal transparency allows voters, interest groups, and competing political parties to observe - or infer with better precision - causes and consequences of a government's fiscal policy, either directly or through the media". In fact, the correlation of media freedom with the index of fiscal policy transparency from the International Budget Partnership is high (0.64) in the context of our sample, albeit the latter variable's limited availability (only after 2005) does not allow us to compare the relative importance of fiscal transparency with other conditioning factors in a feasible manner. Overall, acknowledging the links between media freedom and different conditioning factors of PBCs, our results suggest that media freedom may be the fundamental component which makes those factors important.

This study is also related to Hollyer et al. (2011), who argue that greater electoral accountability induces governments to disclose more relevant economic data and, hence, to become more transparent. Since media freedom and fiscal transparency are related, their results suggest that democratic 
governments promote transparency and media freedom to a greater extent than authoritarian ones. In a study considering both democracies and autocracies, media freedom could be affected by the electoral motives of the incumbent. However, our sample only includes democracies and observations (countryyear pairs) for which the required fiscal data to calculate budget deficits is available. By only considering democratic and transparent governments (according to the definitions of Hollyer et al., 2011), we considerably increase the extent to which media freedom is exogenous to the incumbent's electoral motives.

Next, why is the election-year rise in budget deficits under low media freedom particularly driven by the rise in current spending? To shed light on this question, it is useful to refer to Rogoff (1990), who argues that capital expenditure, which often takes long to materialize, may not be as suitable to signal the incumbent policymaker's competence as immediately-observed current spending. Subsequently, our finding has an important policy implication. That is, if a country considers implementing fiscal rules to avoid fluctuations in discretionary fiscal policies under low media freedom, it would be critical to impose a rule on the current component of public spending. Although the supplementary results for subcomponents of public expenditures and revenues are relatively weak, mainly due to the smaller number of available observations, they suggest that under low media freedom, public wages increase and personal income taxes decrease in election years. Public finances seem to be managed in a voter-friendly way in order to gain votes.

To conclude, as stated in the Freedom House's website, media freedom/independence "plays a key role in sustaining and monitoring a healthy democracy, as well as in contributing to greater accountability, good government, and economic development." (https://freedomhouse.org/reporttypes/freedom-press). This paper highlights the role of media freedom in the context of electoral opportunism. When media freedom is low, governments control the viewpoints that reach citizens, and the latter have fewer chances of being well informed of governments' fiscal behavior in election years. As 
our results indicate, it is under these circumstances that policymakers manipulate fiscal policies most actively, mainly via current spending policies.

\section{Acknowledgements}

The authors thank Henry Chappell, Fabio Padovano, Klaus H. Goetz, Toke Aidt, and three anonymous referees for very valuable comments. This work was carried within the funding with reference UID/ECO/03182/2013 (project 6683), with the FCT/MEC's financial support through national funding and by the ERDF through the Operational Programme on Competitiveness and Internationalization COMPETE 2020 under the PT2020 Partnership Agreement. This research was also partially supported by the Programa Operacional da Região Norte, NORTE2020, in the context of project NORTE-01-0145-FEDER000037 (SmartEGOV).

\section{References}

Aidt, Toke S., Francisco José Veiga, and Linda Gonçalves Veiga (2011). “Election results and opportunistic policies: A new test of the rational political business cycle model." Public Choice 148: 21-44.

Akhmedov, Akhmed, and Ekaterina Zhuravskaya (2004). "Opportunistic political cycles: Test in a young democracy setting." The Quarterly Journal of Economics 119(4): 1301-1338.

Alesina, Alberto, and Guido Tabellini (1990). "A positive theory of fiscal deficits and government debt." The Review of Economic Studies 57(3): 403-414.

Alt, James E., and David Dryer Lassen (2006a). "Fiscal transparency, political parties, and debt in OECD countries." European Economic Review 50: 1403-1439.

Alt, James E., and David Dryer Lassen (2006b). "Transparency, political polarization, and political budget cycles in OECD countries." American Journal of Political Science 50(3): 530-550. 
Alt, James E., and Shanna Rose (2007). "Context-conditioned political budget cycles." In C. Boix and S.C. Stokes (eds.) Oxford Handbook of Comparative Politics, New York, NY: Oxford University Press: 845867.

Arellano, Manuel, and Stephen Bond (1991). "Some tests of specification for panel data: Monte Carlo evidence and an application to employment equations." The Review of Economic Studies 58, 277-297. Arellano, Manuel, and Olympia Bover (1995). "Another look at the instrumental variable estimation of error-component models." Journal of Econometrics 68, 29-51.

Beck, Thorsten, George Clarke, Alberto Groff, Philip Keefer, and Patrick Walsh (2001). "New tools in comparative political economy: the database of political institutions." World Bank Economic Review $15,165-176$.

Besley, Tim, and Andrea Prat (2006). "Handcuffs for the grabbing hand? Media capture and government accountability." American Economic Review 96(3): 720-736.

Blundell, Richard, and Stephen Bond (1998). "Initial conditions and moment restrictions in dynamic panel data models." Journal of Econometrics 87: 115-143.

Brender, Adi, and Allen Drazen (2005). "Political budget cycles in new versus established democracies." Journal of Monetary Economics 52(7): 1271-1295.

Brender, Adi, and Allen Drazen (2013). "Elections, leaders, and the composition of government spending." Journal of Public Economics 97: 18-31.

Chang, Eric C. C. (2008). "Electoral Incentives and Budgetary Spending: Rethinking the Role of Political Institutions." The Journal of Politics 70(4): 1086-1097.

Cheibub, José Antonio, Jennifer Gandhi, and James Raymond Vreeland (2010). “Democracy and dictatorship revisited." Public Choice 143, 67-101.

de Haan, Jakob, and Jeroen Klomp (2013). "Conditional political budget cycles: a review of recent evidence." Public Choice 157: 387-410. 
Djankov, Simeon, Caralee McLiesh, Tatiana Nenova, and Andrei Schleifer (2003). “Who owns the media?” Journal of Law and Economics 46: 341-381.

Drazen, Allan, and Marcela Eslava (2010). “Electoral manipulation via voter-friendly spending: Theory and evidence." Journal of Development Economics 92: 39-52.

Dubois, Eric (2016). "Political business cycles 40 years after Nordhaus." Public Choice 166, 235-259.

Efthyvoulou, Georgios (2012). "Political budget cycles in the European Union and the impact of political pressures." Public Choice 153: 295-327.

Franzese, Robert J., Jr. (2002). "Electoral and partisan cycles in economic policies and outcomes." Annual Review of Political Science 5: 369-421.

Frey, Bruno S., and Friedrich Schneider (1978a). "An empirical study of politico-economic interaction in the United States." The Review of Economics and Statistics 60: 1974-183.

Frey, Bruno S., and Friedrich Schneider (1978b). "A politico-economic model of the United Kingdom." The Economic Journal 88: 243-253.

Henisz, Witold J. (2000). "The institutional environment for economic growth." Economics and Politics 12(1): 1-31.

Hibbs, Douglas (1977). "Political parties and macroeconomic policy." American Political Science Review 71(4): 467-87.

Hollyer, James R., B. Peter Rosendorff, and James Raymond Vreeland (2011). "Democracy and Transparency." The Journal of Politics 73: 1191-1205.

Katsimi, Margarita, and Vassilis Sarantides (2012). "Do elections affect the composition of fiscal policy in developed, established democracies?" Public Choice 151: 325-362.

Leeson, Peter T. (2008). "Media freedom, political knowledge, and Participation." Journal of Economic Perspectives 22: 155-170.

Nordhaus, William (1975). “The political business cycle.” The Review of Economic Studies 42(2): 169-1990. 
Persson, Torsten, and Guido Tabellini (2000). Political Economics - Explaining Economic Policy. Cambridge: MIT Press.

Persson, Torsten, and Guido Tabellini (2003). The economic effect of constitutions: what do the data say. Cambridge: MIT Press.

Rogoff, Kenneth, and Anne Sibert (1988). "Elections and macroeconomic policy cycles." Review of Economics Studies 55: 1-16.

Rogoff, Kenneth (1990). “Equilibrium political budget cycles." American Economic Review 80: 21-36.

Shelton, Cameron A. (2014). "Legislative budget cycles." Public Choice 159: 251-275.

Shi, Min, and Jakob Svensson (2006). "Political budget cycles: do they differ across countries and why?" Journal of Public Economics 90(8-9): 1367-89.

Tufte, Edward R. (1978). Political Control of the Economy. Princeton, New Jersey: Princeton University Press.

Veiga, Francisco José (2010). "Political Business Cycles." In The Encyclopedia of Political Science, eds. George Thomas Kurian, James E. Alt, Simone Chambers, Geoffrey Garrett, Margaret Levi, and Paula D. McClain. Washington, DC: CQ Press, 169-170.

Veiga, Linda Gonçalves, and Francisco José Veiga (2007). "Political business cycles at the municipal level." Public Choice 131: 45-64.

Vergne, Clément (2009). "Democracy, elections and allocation of public expenditures in developing countries." European Journal of Political Economy 25: 63-77.

Vreeland, James Raymond (2008). "The effect of political regime on civil war: unpacking anocracy." Journal of Conflict Resolution 52(3): 401-425.

Warf, Barney (2012). "Global internet censorship." In Global Geographies of the internet. Springer Briefs in Geography, pp. 45-75. 
Wickens, Tobias M. (2002). Government Finance Statistics Manual 2001 Companion Material: Classification of GFSM 1986 data to the GFSM 2001 framework. Washington, DC: International Monetary Fund. 
Table 1. Electoral effects on the deficit and media diffusion and freedom

\begin{tabular}{|c|c|c|c|c|c|c|c|c|c|c|}
\hline & \multirow{2}{*}{\multicolumn{2}{|c|}{ All elections }} & \multicolumn{8}{|c|}{ Sub-samples } \\
\hline & & & \multicolumn{2}{|c|}{ Predetermined } & \multicolumn{2}{|c|}{ Close elections } & \multicolumn{2}{|c|}{ New Democracies } & \multicolumn{2}{|c|}{ Proportional } \\
\hline & SysGMM & $\mathrm{FE}$ & SysGMM & $\mathrm{FE}$ & SysGMM & FE & SysGMM & FE & SysGMM & $\mathrm{FE}$ \\
\hline & (1) & (2) & (3) & (4) & (5) & (6) & (7) & (8) & (9) & (10) \\
\hline IMD_Low*Election_year & $\begin{array}{c}1.024^{* * *} \\
(3.107)\end{array}$ & $\begin{array}{c}0.973 * * * \\
(3.611)\end{array}$ & $\begin{array}{l}0.974 * * \\
(2.318)\end{array}$ & $\begin{array}{c}1.230 * * * \\
(3.475)\end{array}$ & $\begin{array}{c}1.285^{* * *} \\
(3.740)\end{array}$ & $\begin{array}{c}1.053^{* * *} \\
(4.048)\end{array}$ & $\begin{array}{l}0.720^{*} \\
(1.753)\end{array}$ & $\begin{array}{l}0.887^{*} \\
(2.017)\end{array}$ & $\begin{array}{l}0.794^{* *} \\
(2.122)\end{array}$ & $\begin{array}{c}1.256^{* * *} \\
(3.696)\end{array}$ \\
\hline IMD_High*Election_year & $\begin{array}{l}0.270^{*} \\
(1.721)\end{array}$ & $\begin{array}{l}0.149 \\
(0.966)\end{array}$ & $\begin{array}{l}0.156 \\
(0.772)\end{array}$ & $\begin{array}{c}0.233 \\
(1.321)\end{array}$ & $\begin{array}{c}0.305 \\
(1.089)\end{array}$ & $\begin{array}{l}-0.017 \\
(-0.065)\end{array}$ & $\begin{array}{c}0.626 \\
(1.018)\end{array}$ & $\begin{array}{c}0.356 \\
(0.940)\end{array}$ & $\begin{array}{c}0.327 \\
(1.642)\end{array}$ & $\begin{array}{c}0.190 \\
(0.932)\end{array}$ \\
\hline Wald, p-value & 0.04 & 0.02 & 0.09 & 0.02 & 0.01 & 0.01 & 0.90 & 0.38 & 0.26 & 0.02 \\
\hline $\begin{array}{l}\text { Media_freedom_Low* } \\
\text { Election_year }\end{array}$ & $\begin{array}{c}1.085^{* * *} \\
(3.539)\end{array}$ & $\begin{array}{c}0.960 * * * \\
(3.349)\end{array}$ & $\begin{array}{c}1.191^{* * *} \\
(2.805)\end{array}$ & $\begin{array}{c}1.378 * * * \\
(3.627)\end{array}$ & $\begin{array}{c}1.419 * * * \\
(4.502)\end{array}$ & $\begin{array}{c}1.023 * * * \\
(3.181)\end{array}$ & $\begin{array}{c}1.138 * * * \\
(2.964)\end{array}$ & $\begin{array}{l}1.051^{* *} \\
(2.450)\end{array}$ & $\begin{array}{c}1.122^{* * *} \\
(2.793)\end{array}$ & $\begin{array}{c}1.619 * * * \\
(4.295)\end{array}$ \\
\hline Media_freedom_High* & $0.351^{*}$ & 0.227 & 0.156 & 0.255 & 0.230 & 0.142 & -0.049 & 0.161 & $0.321 *$ & 0.195 \\
\hline Election_year & $(1.896)$ & $(1.482)$ & $(0.882)$ & (1.479) & $(1.000)$ & $(0.538)$ & $(-0.122)$ & $(0.422)$ & $(1.786)$ & (1.184) \\
\hline Wald test, $p$-value & 0.03 & 0.03 & 0.03 & 0.008 & 0.00 & 0.04 & 0.04 & 0.14 & 0.07 & 0.004 \\
\hline Radios_pc_Low*Election_year & $\begin{array}{c}0.981^{* * *} \\
(2.759)\end{array}$ & $\begin{array}{c}0.890^{* * *} \\
(3.267)\end{array}$ & $\begin{array}{c}0.882^{* *} \\
(2.168)\end{array}$ & $\begin{array}{c}1.151^{* * *} \\
(3.222)\end{array}$ & $\begin{array}{c}1.280^{* * *} \\
(3.826)\end{array}$ & $\begin{array}{c}0.938^{* * *} \\
(3.607)\end{array}$ & $\begin{array}{c}0.794^{* *} \\
(2.127)\end{array}$ & $\begin{array}{c}0.945^{* *} \\
(2.255)\end{array}$ & $\begin{array}{c}0.579 \\
(1.054)\end{array}$ & $\begin{array}{c}1.107^{* * *} \\
(3.238)\end{array}$ \\
\hline Radios_pc_High*Election_year & $\begin{array}{l}0.417^{*} \\
(1.855)\end{array}$ & $\begin{array}{c}0.220 \\
(1.239)\end{array}$ & $\begin{array}{c}0.331 \\
(1.285)\end{array}$ & $\begin{array}{c}0.292 \\
(1.431)\end{array}$ & $\begin{array}{c}0.368 \\
(1.194)\end{array}$ & $\begin{array}{c}0.060 \\
(0.216)\end{array}$ & $\begin{array}{c}0.381 \\
(0.723)\end{array}$ & $\begin{array}{l}0.116 \\
(0.321)\end{array}$ & $\begin{array}{c}0.480 \\
(1.194)\end{array}$ & $\begin{array}{c}0.299 \\
(1.218)\end{array}$ \\
\hline Wald, p-value & 0.17 & 0.06 & 0.28 & 0.05 & 0.02 & 0.03 & 0.52 & 0.18 & 0.90 & 0.11 \\
\hline $\begin{array}{l}\text { Radio\&TV\&Newspaper_Low* } \\
\text { Election_year }\end{array}$ & $\begin{array}{l}0.956 * * * \\
(3.005)\end{array}$ & $\begin{array}{l}0.755^{* * *} \\
(2.696)\end{array}$ & $\begin{array}{l}0.874^{* *} \\
(2.212)\end{array}$ & $\begin{array}{c}1.047^{* * *} \\
(2.989)\end{array}$ & $\begin{array}{c}1.163^{* * *} \\
(3.446)\end{array}$ & $\begin{array}{l}0.912 * * * \\
(3.465)\end{array}$ & $\begin{array}{l}0.617^{*} \\
(1.691)\end{array}$ & $\begin{array}{l}0.724^{*} \\
(1.826)\end{array}$ & $\begin{array}{l}0.630^{*} \\
(1.668)\end{array}$ & $\begin{array}{l}0.959 * * \\
(2.680)\end{array}$ \\
\hline Radio\&TV\&Newspaper_High* & $0.427^{* *}$ & $0.344^{*}$ & 0.296 & $0.378^{*}$ & 0.422 & 0.120 & 0.799 & 0.524 & $0.579 * *$ & $0.414^{*}$ \\
\hline Election_year & $(2.148)$ & $(1.935)$ & $(1.140)$ & $(1.696)$ & (1.411) & $(0.421)$ & (1.338) & $(0.877)$ & $(2.362)$ & $(1.685)$ \\
\hline Wald test, $p$-value & 0.15 & 0.26 & 0.26 & 0.138 & 0.08 & 0.06 & 0.77 & 0.79 & 0.91 & 0.29 \\
\hline Number of observations & 884 & 884 & 652 & 652 & 502 & 502 & 373 & 373 & 574 & 574 \\
\hline Number of countries & 69 & 69 & 63 & 63 & 54 & 54 & 43 & 43 & 42 & 42 \\
\hline $\begin{array}{l}\text { Internet_users_Low* } \\
\text { Election_year }\end{array}$ & $\begin{array}{c}0.962^{* * *} \\
(3.189)\end{array}$ & $\begin{array}{l}0.601^{* *} \\
(2.628)\end{array}$ & $\begin{array}{l}0.707^{* *} \\
(2.440)\end{array}$ & $\begin{array}{c}0.773 * * * \\
(2.928)\end{array}$ & $\begin{array}{c}0.830 * * * \\
(2.627)\end{array}$ & $\begin{array}{c}0.691 * * * \\
(2.942)\end{array}$ & $\begin{array}{c}0.731^{* *} \\
(2.025)\end{array}$ & $\begin{array}{c}0.520 \\
(1.270)\end{array}$ & $\begin{array}{c}1.064^{* * *} \\
(3.749)\end{array}$ & $\begin{array}{c}0.849 * * * \\
(3.565)\end{array}$ \\
\hline Internet_users_High* & -0.925 & -0.789 & -0.866 & 0.056 & -0.819 & -0.687 & $-4.035^{* *}$ & $-1.295^{* *}$ & -0.882 & -0.485 \\
\hline Election_year & $(-1.288)$ & $(-1.264)$ & $(-0.869)$ & $(0.087)$ & $(-0.720)$ & $(-1.080)$ & $(-2.147)$ & $(-2.447)$ & $(-0.882)$ & $(-0.631)$ \\
\hline Wald test, $\mathrm{p}$-value & 0.01 & 0.04 & 0.12 & 0.30 & 0.16 & 0.04 & 0.01 & 0.01 & 0.05 & 0.12 \\
\hline Number of observations & 576 & 576 & 435 & 435 & 348 & 348 & 251 & 251 & 389 & 389 \\
\hline Number of countries & 65 & 65 & 59 & 59 & 50 & 50 & 38 & 38 & 41 & 41 \\
\hline
\end{tabular}

Sources: IMF (GFS and WEO); World Bank (DPI and WDI), and Cheibub et al. (2010).

Notes: $\quad$ Estimated model (equation 2): $f_{i t}=\alpha f_{i, t-1}+\beta_{1}\left(E L Y_{i t} * D_{i t}\right)+\beta_{2}\left(E L Y_{i t} *\left(1-D_{i t}\right)\right)+\varnothing D_{i t}+\boldsymbol{X}^{\prime}{ }_{i t} \boldsymbol{\delta}+\mu_{i}+\varepsilon_{i t}$. Sample of elections in democracies (defined as in Cheibub et al. 2010), from 1975 to 2010. Two-step results using robust standard errors corrected for finite samples are reported in System-GMM (Sys-GMM). Robust standard errors are reported in Fixed Effects (FE) estimations. Log(GDPpc 2005). Trade (\%GDP) and Output gap were treated as endogenous in the Sys-GMM estimations. Their lagged values two periods were used as instruments in the first-difference equations and their once lagged first-differences were used in the levels equation. The option collapse of the command xtabond2 for Stata was used in order to avoid a very high number of instruments. These variables were lagged one period in the FE estimations in order to avoid simultaneity/endogeneity problems. T-statistics in parenthesis. Significance level at which the null hypothesis is rejected: ${ }^{* * *}, 1 \%$; ${ }^{* *}, 5 \%$, and ${ }^{*}, 10 \%$, 
Table 2. Electoral effects on the deficit and media freedom - all conditions included simultaneously

\begin{tabular}{|c|c|c|c|c|}
\hline & (1) & (2) & (3) & (4) \\
\hline & SysGMM & $\mathrm{FE}$ & SysGMM & $\mathrm{FE}$ \\
\hline \multirow[t]{2}{*}{ L.Deficit (\% GDP) } & $0.960 * * *$ & $0.729 * * *$ & $0.961 * * *$ & $0.732^{* * *}$ \\
\hline & $(4.663)$ & (9.081) & $(4.706)$ & $(9.050)$ \\
\hline \multirow[t]{2}{*}{ Election year } & -0.016 & -0.805 & 0.190 & -0.761 \\
\hline & $(-0.024)$ & $(-1.667)$ & $(0.266)$ & $(-1.586)$ \\
\hline \multirow[t]{2}{*}{ Media_freedom_Low*Election_year } & $0.779 *$ & $0.927^{* *}$ & $0.771^{*}$ & $0.842 * *$ \\
\hline & $(1.703)$ & $(2.560)$ & $(1.723)$ & $(2.411)$ \\
\hline \multirow[t]{2}{*}{ Media_freedom_Low } & 3.355 & 0.232 & 2.772 & 0.245 \\
\hline & $(1.381)$ & $(0.839)$ & $(1.250)$ & $(0.944)$ \\
\hline \multirow[t]{2}{*}{ Radios_pc_Low*Election_year } & & & 0.118 & 0.493 \\
\hline & & & $(0.224)$ & $(1.200)$ \\
\hline \multirow[t]{2}{*}{ Radios_pc_Low } & & & 2.814 & $0.939 *$ \\
\hline & & & $(0.927)$ & $(1.675)$ \\
\hline \multirow[t]{2}{*}{ TVs_pc_Low*Election_year } & & & -0.392 & -0.359 \\
\hline & & & $(-0.881)$ & $(-0.979)$ \\
\hline \multirow[t]{2}{*}{ TVs_pc_Low } & & & -2.523 & -0.025 \\
\hline & & & $(-0.946)$ & $(-0.084)$ \\
\hline \multirow[t]{2}{*}{ Newspapers_pc_Low*Election_year } & & & 2.973 & -0.307 \\
\hline & & & $(1.170)$ & $(-0.721)$ \\
\hline \multirow[t]{2}{*}{ Newspapers_pc_Low } & & & 2.740 & -0.303 \\
\hline & & & (1.159) & $(-0.715)$ \\
\hline \multirow[t]{2}{*}{ Predetermined_Election *Election_year } & 0.002 & 0.458 & -0.045 & 0.431 \\
\hline & $(0.003)$ & $(1.310)$ & $(-0.093)$ & $(1.226)$ \\
\hline \multirow[t]{2}{*}{ Predetermined_Election } & -1.343 & $-0.647^{* *}$ & -1.221 & $-0.639 * *$ \\
\hline & $(-1.529)$ & $(-2.102)$ & $(-1.346)$ & $(-2.099)$ \\
\hline \multirow[t]{2}{*}{ Close_election*Election_year } & 0.341 & 0.052 & 0.257 & 0.017 \\
\hline & $(0.784)$ & $(0.143)$ & $(0.562)$ & $(0.051)$ \\
\hline \multirow[t]{2}{*}{ Close election } & 0.906 & 0.036 & 1.012 & 0.038 \\
\hline & (0.874) & (0.149) & $(0.864)$ & $(0.154)$ \\
\hline \multirow[t]{2}{*}{ New_democracy*Election_year } & 0.158 & 0.241 & 0.146 & 0.235 \\
\hline & $(0.316)$ & $(0.667)$ & $(0.306)$ & $(0.584)$ \\
\hline \multirow[t]{2}{*}{ New democracy } & 0.432 & 0.236 & 0.364 & 0.272 \\
\hline & $(0.197)$ & $(0.440)$ & $(0.206)$ & $(0.486)$ \\
\hline \multirow[t]{2}{*}{ Proportional*Election_year } & 0.232 & $0.748 * *$ & 0.121 & $0.707^{* *}$ \\
\hline & (0.439) & $(2.337)$ & $(0.200)$ & $(2.218)$ \\
\hline \multirow[t]{2}{*}{ Proportional } & -1.692 & $0.686 * *$ & -1.954 & $0.624^{* *}$ \\
\hline & $(-0.881)$ & $(2.540)$ & $(-0.985)$ & $(2.040)$ \\
\hline Number of observations & 884 & 884 & 884 & 884 \\
\hline \multirow{2}{*}{\multicolumn{5}{|c|}{$\begin{array}{l}\text { Number of countries } \\
\text { Marginal effects of Election_year: }\end{array}$}} \\
\hline & & & & \\
\hline Over Media_freedom_Low & 0.06 & 0.03 & 0.06 & 0.01 \\
\hline Over Radios_pc_Low & & & 0.32 & 0.03 \\
\hline Over TVs_pc_Low & & & 0.79 & 0.43 \\
\hline Over Newspapers_pc_Low & & & 0.39 & 0.31 \\
\hline Over Predetermined_Election & 0.93 & 0.21 & 0.81 & 0.26 \\
\hline Over Close election & 0.37 & 0.59 & 0.51 & 0.62 \\
\hline Over New democracy & 0.38 & 0.14 & 0.38 & 0.14 \\
\hline Over Proportional & 0.90 & 0.06 & 0.93 & 0.06 \\
\hline
\end{tabular}

Sources: IMF (GFS and WEO); World Bank (DPI and WDI), and Cheibub et al. (2010).

Notes: See notes of Table 1.

- Estimated model (equation 3): $f_{i t}=\alpha f_{i, t-1}+\beta E L Y_{i t}+\sum_{k=1}^{m}\left[\gamma_{k}\left(E L Y_{i t} * D_{k i t}\right)+\emptyset_{k} D_{k i t}\right]+\boldsymbol{X}_{i t}^{\prime} \boldsymbol{\delta}+\mu_{i}+\varepsilon_{i t}$ 
Table 3. Media freedom and electoral effects on the composition of expenditure and revenue

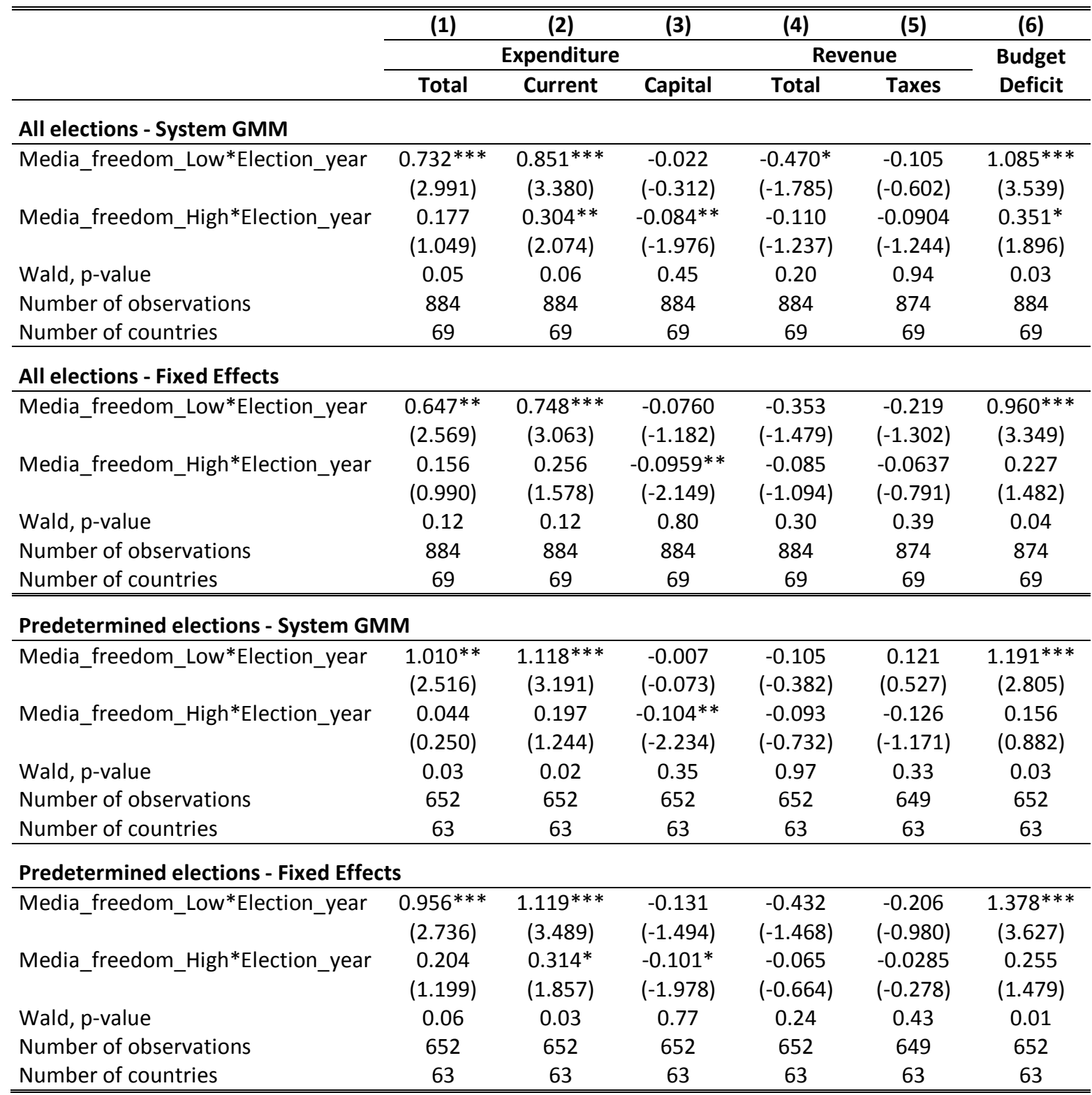

Sources: IMF (GFS and WEO); World Bank (DPI and WDI), and Cheibub et al. (2010).

Notes: All elections in democracies (defined as in Cheibub et al. 2010). Sample period: 1975-2010. Estimated model:

$f_{i t}=\alpha f_{i, t-1}+\beta_{1}\left(E L Y_{i t} *\right.$ MedFreeH $\left._{i t}\right)+\beta_{2}\left(E L Y_{i t} *\right.$ MedFreeL $\left._{i t}\right)+\emptyset$ MedFreeH $_{i t}+\boldsymbol{X}^{\prime}{ }_{i t} \boldsymbol{\delta}+\mu_{i}+\varepsilon_{i t}$

Two-step results using robust standard errors corrected for finite samples are reported in System-GMM (Sys-GMM). Robust standard errors are reported in Fixed Effects (FE) estimations. Log(GDPpc 2005), Trade (\%GDP) and Output gap were treated as endogenous in the Sys-GMM estimations. Their lagged values two periods were used as instruments in the first-difference equations and their once lagged first-differences were used in the levels equation. The option collapse of the command xtabond2 for Stata was used in order to avoid a very high number of instruments. These variables were lagged one period in the FE estimations in order to avoid simultaneity/endogeneity problems. t-statistics in parenthesis. Significance level at which the null hypothesis is rejected: ${ }^{* * *}, 1 \% ; * *, 5 \%$, and $*, 10 \%$. 
Table 4. Composition of expenditure and revenue - sample of Low Media Freedom

\begin{tabular}{|c|c|c|c|c|c|c|c|c|}
\hline & (1) & (2) & (3) & (4) & (5) & (6) & (7) & (8) \\
\hline & \multicolumn{4}{|c|}{ Expenditure } & \multicolumn{3}{|c|}{ Revenue } & \multirow{2}{*}{$\begin{array}{l}\text { Budget } \\
\text { Deficit }\end{array}$} \\
\hline & Total & Current & $\begin{array}{c}\text { Comp. } \\
\text { Employees }\end{array}$ & Capital & Total & Taxes & $\begin{array}{l}\text { Personal } \\
\text { Inc. Tax. }\end{array}$ & \\
\hline \multicolumn{9}{|c|}{ All elections- System GMM } \\
\hline Election_year & $\begin{array}{c}0.638^{* * *} \\
(2.781)\end{array}$ & $\begin{array}{c}0.743^{* * *} \\
(3.288)\end{array}$ & $\begin{array}{l}0.106 * \\
(1.747)\end{array}$ & $\begin{array}{c}-0.032 \\
(-0.603)\end{array}$ & $\begin{array}{c}-0.237 \\
(-1.398)\end{array}$ & $\begin{array}{c}-0.209 \\
(-0.866)\end{array}$ & $\begin{array}{c}-0.185^{*} \\
(-1.724)\end{array}$ & $\begin{array}{c}0.904^{* * *} \\
(3.097)\end{array}$ \\
\hline N. of observations & 418 & 418 & 402 & 418 & 418 & 418 & 298 & 418 \\
\hline Number of countries & 54 & 54 & 53 & 54 & 54 & 54 & 35 & 54 \\
\hline \multicolumn{9}{|c|}{ All elections - Fixed Effects } \\
\hline Election_year & $\begin{array}{c}0.581 * * \\
(2.520)\end{array}$ & $\begin{array}{c}0.663^{* * *} \\
(2.934)\end{array}$ & $\begin{array}{l}0.124^{*} \\
(1.730)\end{array}$ & $\begin{array}{l}-0.0771 \\
(-1.191)\end{array}$ & $\begin{array}{c}-0.357 \\
(-1.661)\end{array}$ & $\begin{array}{l}-0.257^{*} \\
(-1.708)\end{array}$ & $\begin{array}{c}-0.157^{* *} \\
(-2.215)\end{array}$ & $\begin{array}{c}0.841 * * * \\
(3.289)\end{array}$ \\
\hline N. of observations & 418 & 418 & 402 & 418 & 418 & 418 & 298 & 418 \\
\hline Number of countries & 54 & 54 & 53 & 54 & 54 & 54 & 35 & 54 \\
\hline \multicolumn{9}{|c|}{ Predetermined elections - System GMM } \\
\hline Election_year & $\begin{array}{c}0.866 * * \\
(2.035)\end{array}$ & $\begin{array}{c}0.963^{* * *} \\
(3.049)\end{array}$ & $\begin{array}{l}0.170 * \\
(1.745)\end{array}$ & $\begin{array}{c}-0.036 \\
(-0.321)\end{array}$ & $\begin{array}{c}-0.138 \\
(-0.580)\end{array}$ & $\begin{array}{c}0.0256 \\
(0.0900)\end{array}$ & $\begin{array}{c}-0.174^{*} \\
(-1.809)\end{array}$ & $\begin{array}{l}0.846 * \\
(1.693)\end{array}$ \\
\hline N. of observations & 287 & 287 & 281 & 287 & 287 & 287 & 188 & 287 \\
\hline Number of countries & 47 & 47 & 47 & 47 & 47 & 47 & 29 & 47 \\
\hline \multicolumn{9}{|c|}{ Predetermined elections - Fixed Effects } \\
\hline Election_year & $\begin{array}{c}0.812 * * \\
(2.594)\end{array}$ & $\begin{array}{c}0.937 * * * \\
(3.221)\end{array}$ & $\begin{array}{c}0.136 \\
(1.398)\end{array}$ & $\begin{array}{c}-0.121 \\
(-1.351)\end{array}$ & $\begin{array}{l}-0.509 * \\
(-1.730)\end{array}$ & $\begin{array}{l}-0.213 \\
(-1.005)\end{array}$ & $\begin{array}{c}-0.202 * * \\
(-2.604)\end{array}$ & $\begin{array}{c}1.317^{* * *} \\
(3.664)\end{array}$ \\
\hline N. of observations & 287 & 287 & 281 & 287 & 287 & 287 & 188 & 287 \\
\hline Number of countries & 47 & 47 & 47 & 47 & 47 & 47 & 29 & 47 \\
\hline
\end{tabular}

Sources: IMF (GFS and WEO); World Bank (DPI and WDI), and Cheibub et al. (2010).

Notes:

- All elections in democracies (defined as in Cheibub et al. 2010) with low IMD. Sample period: 1975-2010.

- Estimated model (equation 1): $f_{i t}=\alpha f_{i, t-1}+\beta E L Y_{i t}+\boldsymbol{X}_{i t}^{\prime} \boldsymbol{\delta}+\mu_{i}+\varepsilon_{i t}$

- Two-step results using robust standard errors corrected for finite samples are reported in System-GMM (Sys-GMM). Robust standard errors are reported in Fixed Effects (FE) estimations.

- Log(GDPpc 2005), Trade (\%GDP) and Output gap were treated as endogenous in the Sys-GMM estimations. Their lagged values two periods were used as instruments in the first-difference equations and their once lagged first-differences were used in the levels equation. The option collapse of the command xtabond2 for Stata was used in order to avoid a very high number of instruments. These variables were lagged one period in the FE estimations in order to avoid simultaneity/endogeneity problems. - $t$-statistics in parenthesis. Significance level at which the null hypothesis is rejected: ${ }^{* *}, 1 \% ; * *, 5 \%$, and $*, 10 \%$. 